\title{
Effect of an Aqueous Extract of Alchornea Cordifolia (Euphorbiacea) Leaves on Sperm Parameters and Reproductive Function of Male Wistar Rats
}

\author{
Kone Allassane \\ Laboratory of Biology and Health, UFR Biosciences, \\ Félix Houphouet-Boigny University, Abidjan, Côte d'Ivoire \\ Gnahoue Goueh \\ Biochemical Microbiological Laboratory of SVT, \\ Higher Teacher School of Côte d'Ivoire \\ Diabate Daouda \\ Kouakou Koffi \\ Laboratory of Biology and Health, UFR Biosciences, \\ Félix Houphouet-Boigny University, Abidjan, Côte d'Ivoire
}

Doi:10.19044/esj.2021.v17n17p236

Submitted: 12 January 2021

Accepted: 19 March 2021

Published: 31 May 2021
Copyright 2021 Author(s)

Under Creative Commons BY-NC-ND

4.0 OPEN ACCESS

Cite As:

Allassane K., Goueh G., Daouda D. \& Koffi K. (2021). Effect of an Aqueous Extract of Alchornea Cordifolia (Euphorbiacea) Leaves on Sperm Parameters and Reproductive Function of Male Wistar Rats. European Scientific Journal, ESJ, 17(17), 236.

https://doi.org/10.19044/esj.2021.v17n17p236

\begin{abstract}
Alchornea cordifolia (euphorbiaceae) is a tree whose leaves are used in traditional medicine to cure several health problems. Little information, however, exist on the effects of this herb on the male reproductive system. In order to assess the effect of Alchornea cordifolia on reproductive male parameters and testosterone production, twenty-four male wistar rats divided into four groups of six rats were used. The aqualus extract of Alchornea cordifolia was administered at a dose of $100 \mathrm{mg} / \mathrm{kg}$ of bw, $200 \mathrm{mg} / \mathrm{kg}$ of bw, and $400 \mathrm{mg} / \mathrm{kg}$ of bw per day, orally for 60 days. A significant increase in androgen-dependent organs, testosterone quantity, mobility, and sperm concentration was observed at doses of $200 \mathrm{mg} / \mathrm{kg}$ of bw and $400 \mathrm{mg} / \mathrm{kg}$ of bw. Only the unwinger sperm count significantly increased at the $100 \mathrm{mg} / \mathrm{kg}$ of bw dose. These results revealed that the aqualius extract of the leaves of
\end{abstract}


Alchornea cordifolia has the potential to improve sperm quality and have positive effects on the reproductive system.

Keywords: Alchornea cordifolia, spermatozoa, testosterone, androgenic, reproduction

\section{Introduction}

Reproduction is vital in the existence of all living things. The good functioning of the reproductive system ensures the perpetuation of the species and the demographic balance of the community. Thus, any related disfunction or disturbance results in damage at several levels, which begins from the couple to the social body (Tamboura, 2006). One of the reproductive anomalies is infertility, which is the inability to conceive naturally after a year of frequent unprotected mating (Schlosser et al., 2007). From a responsibility perspective, in most cases, the female is systematically blamed (Akassa et al., 2019). However, Lejeune (1999) has shown that a man and a woman equally share the responsibility for infertility. This contributed to the impetus for research on male reproduction which had long remained in its infancy and noticeably behind the study undertaken in females (Edouard Akono-Nantia et $a l ., 2007)$. Thus, many therapeutic advances have been made in recent years, particularly with the use of pharmaceutical specialities. Unfortunately, these drugs are expensive, and the use of herbal remedies remains necessary for a poor population.

Alchornea cordifolia is among the plants of traditional medicine which have strong therapeutic potentials, and it is primarily used for the treatment of various ailments such as respiratory, gastrointestinal, and genitourinary problem (Adewunmin et al., 2001). Alchornea cordifolia leaves remain effective in the treatment of male fertility problems. Studies conducted by Ajibade and Olayemi (2015) and Ngaha-Njila et al. (2019) have shown that the methanoic extract of Alchornea cordifolia leaves improves male fertility and sperm quality, respectively. Nevertheless, few studies have been done with the aqueous extract. Therefore, the present study was initiated to evaluate the pharmacological effect of aqueous extract of Alchornea cordifolia on sperm parameters and on testosterone production in male wistar rats.

\section{Material and Methods \\ Material \\ Plant Material}

The fresh leaves of Alchornea cordifolia were harvested in October in the Agneby-Tiassa region (Côte d 'Ivoire) precisely in Azaguié. A sample of this plant has been identified at the National Floristic Center (CNF) of Félix 
Houphouet-Boigny University (Côte d'Ivoire). Alchornea cordifolia is registered under CNF herbarium number 322; 1248.

\section{Animal Material}

Male rats (Rattus norvegicus, Muridae) of the Wistar strain, aged 1214 weeks, weighing between 150-180 g, from the animal house of the Normal Superior School, were used in the study of the fertility of the aqueous extract of Alchornea cordifolia.

\section{Methods}

\section{Preparation of the Extract}

The harvested leaves of Alchornea Cordifolia were dried in direct sunlight at room temperature. Thereafter, the dried leaves were grounded using an IKA A10 Labortechnik (Germany) brand mill to obtain a powder. Fifty (50) grams of the obtained powder was extracted by grinding. This was done three times in $1 \mathrm{~L}$ of distilled water in a mixer (Blender) for three minutes each. The homogenate obtained was drained three times on a square cloth. Subsequently, it was filtered successively four times through cotton wool and once using wattman paper $(3 \mathrm{~mm})$. The resulting filtrate was lyophilized to obtain the aqueous total extract of Alchornea cordifolia leaves.

\section{Study of the Pharmacological Effects of Alchornea Cordifolia on Reproduction of Male Rats}

The experiment was carried out on 24 rats. The animals were divided into 4 groups of 6 rats. Lot 1 received $1 \mathrm{ml}$ of distilled water. Lots 2, 3, and 4 received $1 \mathrm{~mL}$ of $100 \mathrm{mg} / \mathrm{kg}$ of bw, $200 \mathrm{mg} / \mathrm{kg}$ of bw, and $400 \mathrm{mg} / \mathrm{kg}$ of bw of total aqueous extract of Alchornea cordifolia for 60 days. Twenty-four (24) hours after the administration of the last dose, the animals were anesthetized with ether and then the sperm were collected. They were subsequently sacrificed by decapitation method, and the blood was collected in dry tubes for testosterone assay. Rats were dissected to remove and weigh the testes, elevator muscle, right epididymis, seminal vesicles, Cowper's gland, adrenal gland, glans, and prostate from each animal. The right testes and the right adrenal gland of the rats were preserved in 10\% formalin for histopathological analysis.

\section{Sperm Collection}

The sperm collection was done according to the method described by Ngoula et al. (2007). The left caudal epididymis is removed by opening the scrotum. Thereafter, it is dilacerated in $10 \mathrm{ml}$ of $9 \% \mathrm{NaCl}$ before being incubated in a water bath at $36^{\circ} \mathrm{C}$ so that the spermatozoa will diffuse in the solution. 


\section{Spermatozoa Mobility}

The mobility of the spermatozoa was assessed by direct examination of the previous solution. Thus, a fine drop of this solution was placed between slide and coverslip (previously maintained at $36{ }^{\circ} \mathrm{R} \mathrm{C}$.). The assessment was made under a light microscope (Olympus CX31RBSF, Philippine) at $100 \times$ magnification. Mobile and still sperm were counted on 5 random fields and the percentage of motile forms was determined from the formula:

$$
\% \text { of motile spermatozoa }=\frac{\text { motile sperm count }}{\text { total number of sperm }} \times 100
$$

\section{Spermatozoa Density in the Epididymis}

The spermatozoa density in the sperm was determined using the cell of Malassez of Kouam et al. (2016). A drop of the water bath was taken and placed on the Malassez cell, which was then covered with a coverslip. The sperm count was carried out under a light microscope (Olympus CX31RBSF, Philippine) at magnification 400 . The number of spermatozoa per $\mathrm{mm}^{3}$ was estimated by the following formula:

$$
\mathrm{N}=\frac{\mathrm{X} \times \mathrm{fd} \times 10^{-6}}{4}
$$

$X=$ Number of spermatozoid counted in 4 grids of 20 small squares of the Malassez cell;

$\mathrm{fd}=$ Dilution factor $(20)$;

$\mathrm{N}=$ Number of spermatozoid per $\mathrm{mm}^{3}$

\section{Relative Weight of Organs Removed}

The relative weight of the organs removed is obtained according to the following formula:

$$
\operatorname{Pr}(\mathrm{g})=\frac{\operatorname{Po}(\mathrm{g})}{\operatorname{Pc}(\mathrm{g})} \times 100(\mathrm{~g})
$$

With Pr: Relative weight, Pc: Body weight; Po: Body weight

\section{Plasma Testosterone Assay}

The amount of testosterone in the rat serum was analyzed using a testosterone kit (Syntron Bioresearch, Inc., Carlsbad, CA, USA). This comprised of a solid phase enzyme immunoenzimatic using the competitive binding principle. 


\section{Histopathological Examination}

For histopathological examination, the right testis and the right adrenal gland of each animal were subjected to a series of dehydration in ethanol baths and embedding in paraffin. $5 \mu \mathrm{m}$ sections were made with a microtome. This was stained with Hematoxylin and Eosin (H\&E) and observed under an optical microscope (Olympus CKX41, Germany).

\section{Results}

\section{Effect of Aqueous Extract of Alchornea Cordifolia on the Body Weight of Rats}

After 60 days of treatment, a slight increase in animal body weight was seen in rats treated with Alchornea cordifolia compared to control animals (Figure 1). However, this difference was not significant.

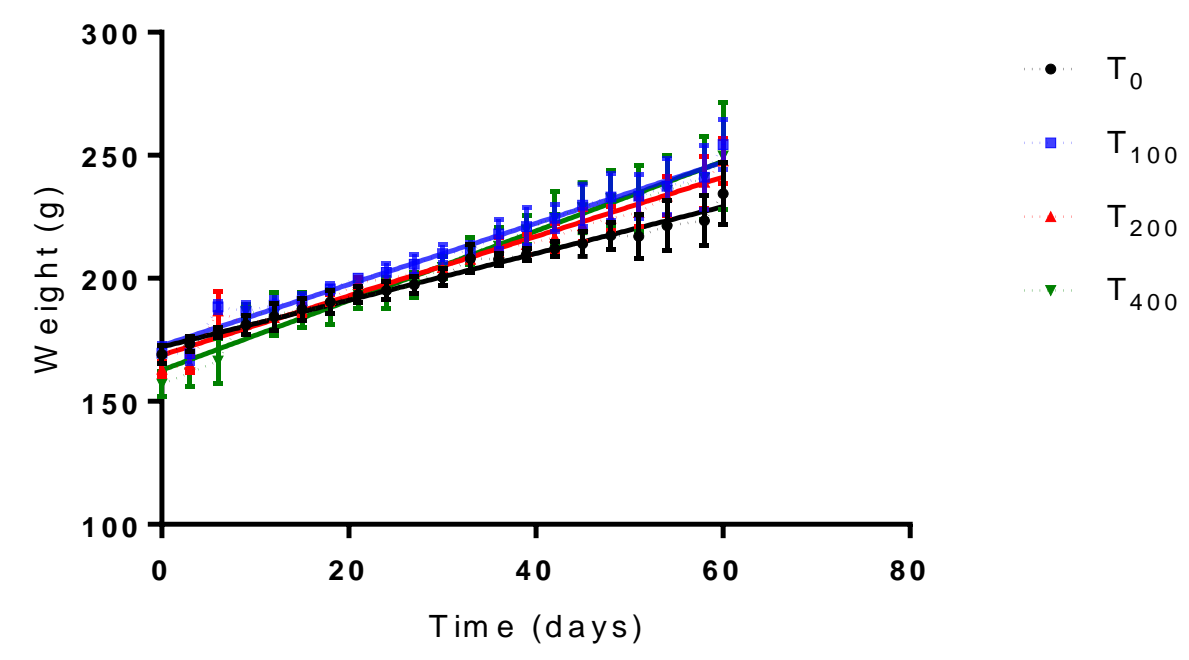

Figure 1. Evolution of the body weight of rats

$\mathrm{T}_{0}$ : distilled water; $\mathrm{T}_{100}: 100 \mathrm{mg} / \mathrm{kg}$ of bw from ETAAC; $\mathrm{T}_{200}: 200 \mathrm{mg} / \mathrm{kg}$ of bw from ETAAC; $\mathrm{T}_{400}: 400 \mathrm{mg} / \mathrm{kg}$ of bw from ETAAC.

\section{Effect of ETAAC on the Weight of Male Reproductive Organs and Adrenal Gland}

After 60 days of treatment, a significant increase was observed in the testes at a dose of $400 \mathrm{mg} / \mathrm{kg}$ of bw. Epididymis, seminal vesicle, prostate, and adrenal gland also increased at doses of $200 \mathrm{mg} / \mathrm{kg}$ of bw and $400 \mathrm{mg} / \mathrm{kg}$ of bw. As for Cowper's gland, glans gland, and elevator muscle, no significant difference was observed between the lots treated with ETAAC compared to the control lot. The results are reported in Table I. 
Table I. Relative weights of reproductive organs and adrenal gland

\begin{tabular}{|c|c|c|c|c|c|c|c|c|}
\hline & Testes & Epididymis & $\begin{array}{l}\text { Seminal } \\
\text { Vesicle }\end{array}$ & Prostate & $\begin{array}{l}\text { Cowper's } \\
\text { Gland }\end{array}$ & Gland & $\begin{array}{l}\text { elevator } \\
\text { muscle }\end{array}$ & Adrenal Gland \\
\hline $\mathrm{T}_{0}$ & $1,05 \pm 0,03$ & $0,18 \pm 0,002$ & $0,46 \pm 0,02$ & $0,21 \pm 0,01$ & $0,024 \pm 0,01$ & $0,075 \pm 0,01$ & $0,033 \pm 0,04$ & $0,0174 \pm 0,001$ \\
\hline $\mathrm{T}_{100}$ & $1,08 \pm 0,02$ & $0,19 \pm 0,003$ & $0,49 \pm 0,01$ & $0,22 \pm 0,02$ & $0,022 \pm 0,01$ & $0,089 \pm 0,02$ & $0,034 \pm 0,02$ & $0,0183 \pm 0,001$ \\
\hline $\mathrm{T}_{200}$ & $1,11 \pm 0,03$ & $0,20 \pm 0,003 *$ & $0,53 \pm 0,01 *$ & $0,25 \pm 0,02 *$ & $0,024 \pm 0,01$ & $0,087 \pm 0,03$ & $0,034 \pm 0,01$ & $\mathbf{0 , 0 1 8 8} \pm \mathbf{0 , 0 0 1 *}$ \\
\hline $\mathrm{T}_{400}$ & $1,13 \pm 0,02 *$ & $0,21 \pm 0,007 * *$ & $0,54 \pm 0,02 *$ & $0,25 \pm 0,01 *$ & $0,025 \pm 0,01$ & $0,088 \pm 0,01$ & $0,036 \pm 0,03$ & $0,0193 \pm 0,001 * *$ \\
\hline
\end{tabular}

\section{Effect of ETAAC on Testosterone Levels}

After 60 days of treatment, a significant increase was observed in the level of serum testosterone at doses of $200 \mathrm{mg} / \mathrm{kg}$ of bw and $400 \mathrm{mg} / \mathrm{kg}$ of bw with a percentage of $34,15 \%$ and $39,14 \%$ respectively. This observation was seen in the treated rats compared to witnesses (Figure 2).

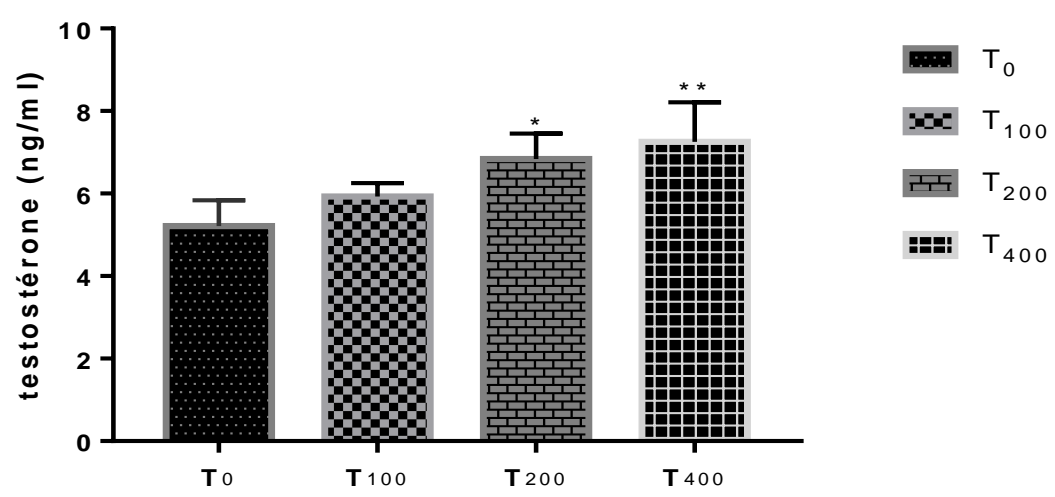

Figure 2. Effect of aqueous extract of aqueous extract of Alchornea cordifolia on testosterone levels

$\mathrm{T}_{0}$ : distilled water; $\mathrm{T}_{100}: 100 \mathrm{mg} / \mathrm{kg}$ of bw; $\mathrm{T}_{200}: 200 \mathrm{mg} / \mathrm{kg}$ of bw; $\mathrm{T}_{400}: 400$ $\mathrm{mg} / \mathrm{kg}$ of bw.

\section{Effect of ETAAC on Sperm Parameters}

Sperm density significantly increased after treatment of rats with aqueous extract of Alchornea cordifolia at doses of $200 \mathrm{mg} / \mathrm{kg}$ of bw and 400 $\mathrm{mg} / \mathrm{kg}$ of bw (Figure 3). The mobile sperm count also significantly increased in rats treated with ETAAC (Figure 4). Sperm morphology was not affected regardless of the dose of extract administered. Almost all sperm were normal in both control and treated rats. 


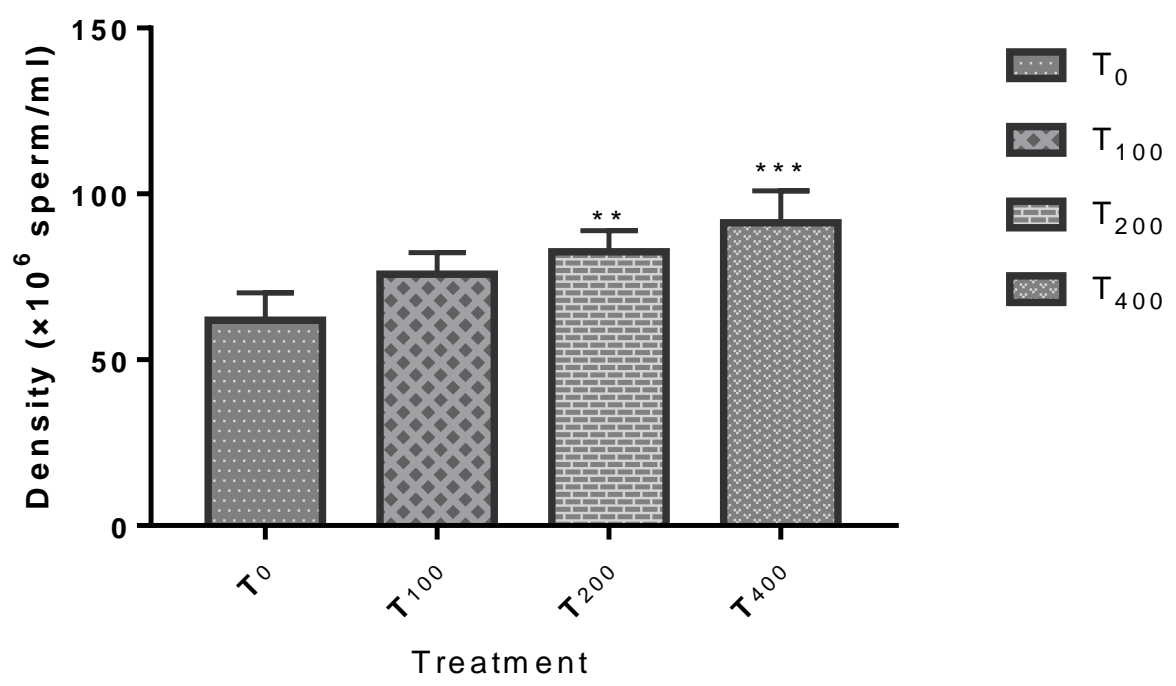

Figure 3. Effect of aqueous extract of Alchornea cordifolia on sperm density

$\mathrm{T}_{0}$ : distilled water; $\mathrm{T}_{100}: 100 \mathrm{mg} / \mathrm{kg}$ of bw; $\mathrm{T}_{200}: 200 \mathrm{mg} / \mathrm{kg}$ of bw; $\mathrm{T}_{400}: 400$ $\mathrm{mg} / \mathrm{kg}$ of bw.

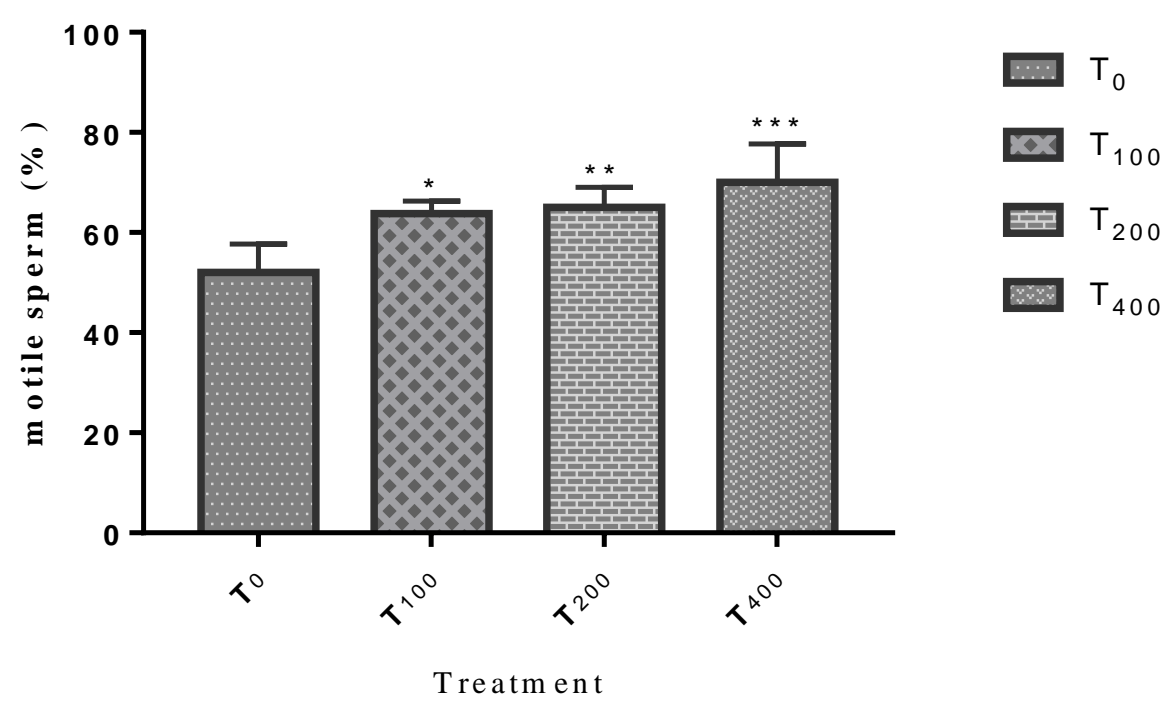

Figure 4. Effect of aqueous extract of Alchornea cordifolia on motile sperm count

$\mathrm{T}_{0}$ : distilled water; $\mathrm{T}_{100}: 100 \mathrm{mg} / \mathrm{kg}$ of bw; $\mathrm{T}_{200}: 200 \mathrm{mg} / \mathrm{kg}$ of bw; $\mathrm{T}_{400}: 400$ $\mathrm{mg} / \mathrm{kg}$ of bw. 


\section{Effect of Aqueous Extract of Alchornea Cordifolia on the Histological Structure of the Testis}

Observation of histological sections of the testes of the rats showed an increase in the volume of the seminiferous tubules in the rats treated with the aqueous extract of Alchornea cordifolia. There was also concentration of sperm in the lumen of the seminiferous tubules.

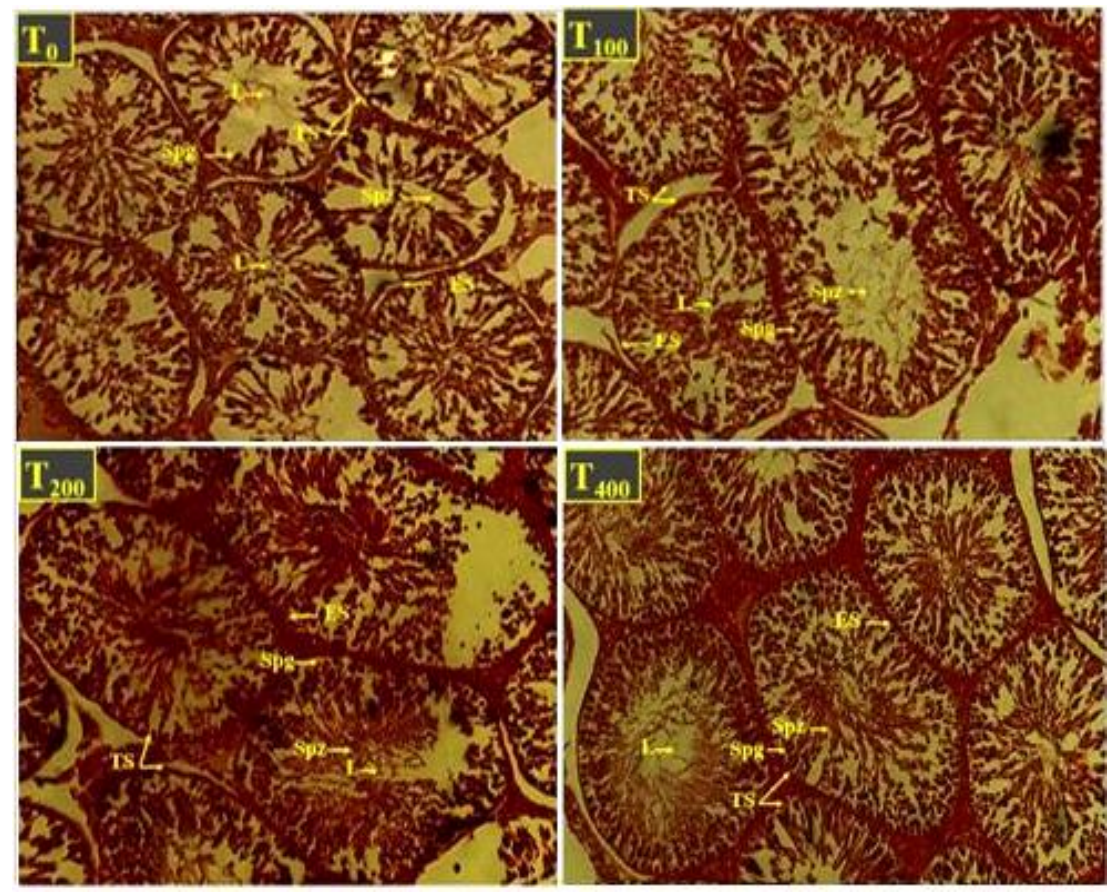

Figure 5. Cross section of testis of control rats and rats treated with different doses of ETAAC

L: Light; TS: Wall of the seminiferous tube; Spg: Spermatogonia; Spz: Spermatozoa; ES: Seminal epithelium; $\mathrm{T}_{0}$ : distilled water; $\mathrm{T}_{100}: 100 \mathrm{mg} / \mathrm{kg}$ of bw; $\mathrm{T}_{200}: 200 \mathrm{mg} / \mathrm{kg}$ of bw; $\mathrm{T}_{400}: 400 \mathrm{mg} / \mathrm{kg}$ of bw; Magnification: $\times 100$ Stain: Hematoxylin eosin

\section{Discussion}

The general objective of the present study was to assess the pharmacological effect of ETAAC on sperm parameters and testosterone production in male rats. After 60 days of treatment, a slight increase in body weight of the treated rats was observed. This could be attributed to the normal growth of the animals during the period. However, the lack of significant difference shows that the aqueous extract of Alchornea cordifolia is believed to have no influence on weight growth. These results are identical to those of Ansah et al. (2011). The significant increase in the weight of certain androgen- 
dependent organs, namely the epididymis, the seminal vesicle and the prostate at the doses of $200 \mathrm{mg} / \mathrm{kg}$ of bw to $400 \mathrm{mg} / \mathrm{kg}$ of bw and the testes at the dose of $400 \mathrm{mg} / \mathrm{kg}$ of bw, demonstrates the androgenic effect of ETAAC. This is because the weight, size, and secretory function of the testes, epididymis, seminal vesicles, and prostate are tightly regulated by androgens (Agarwal et al., 1986). Regarding the epididymis, in addition to the secretions of fluids induced by androgens, the accumulation of sperm in this organ could be the cause of its increase in weight. This result is different from that of Ngaha-Njila et al. (2019) who did not observe a significant difference after 28 days of treatment with a methanolic extract of Alchornea cordifolia. The dosedependent growth of the testes observed is due to steroidogenesis, which is the production of steroid hormones, mainly testosterone, provided by Leydig cells (Stocco, 2002). This testicular increase could be considered as a biological indicator of the effectiveness of the plant in stimulating hormone production (Thakur \& Dixit, 2007). Besides steroidogenesis, the increase in testes could be attributed to stimulation of spermatogenesis, which is the process by which spermatogonia proliferate and turn into mobile sperm (Clermont, 1972). This result differs from that of Ansah et al. (2009) who obtained no significant difference after 14 days of treatment on mice. Nonetheless, the result is close to that of Ajibade and Olayemi (2015) who, after 30 days of treatment with a methanolic extract of Alchornea cordifolia, observed a significant increase in testes at a dose of $400 \mathrm{mg} / \mathrm{kg}$ of bw. The increase in the weight of the seminal vesicles and the prostate observed in this study is due to an intense stimulation of the secretion of the respective seminal and prostatic fluids. This abundance of fluid could be at the origin of the weight growth of these organs (Zougrou, 2017). In rats, any increase in serum testosterone is associated with an increase in the secretory activity of the seminal vesicles and an increase in their weight (Marzouk, 2017). The significant increase in the adrenal gland in rats treated at doses of $200 \mathrm{mg} / \mathrm{kg}$ of bw and $400 \mathrm{mg} / \mathrm{kg}$ of bw was impacted by the production of serum testosterone which increased significantly in this study. It is one of the essential hormones of male physiology. It is also responsible for the development of testicular function, which is the stimulation and maintenance of spermatogenesis (Weinbauer \& Nieschlag, 1998). It is produced by the testes and secondarily by the adrenal glands (Bélanger, 1992). This significant increase in serum testosterone levels of $34,15 \%$ and $39,14 \%$ observed after 60 days of treatment respectively at doses of $200 \mathrm{mg} / \mathrm{kg}$ of bw to $400 \mathrm{mg} / \mathrm{kg}$ of bw, when compared to the controls, indicate that the extract of Alchornea cordifolia behaves as a testosterone agonist by binding to its receptors to mimic its biological activity. These results are also in the same direction as those of Ngaha-Njila et al. (2019) and Ajibade and Olayemi (2015). The increase in serum hormone levels after administration of the aqueous extract of Alchornea cordifolia could also justify the effects observed 
on spermatic function. Therefore, the results obtained indicate that the aqueous extract of Alchornea cordifolia at doses of $200 \mathrm{mg} / \mathrm{kg}$ of bw and $400 \mathrm{mg} / \mathrm{kg}$ of bw causes a significant increase in the concentration in the epididymis and the rate of sperm mobility. In addition, the morphology of the sperm was not affected regardless of the dose of extract administered. Sperm are considered to be mobile cells that provide sensitive parameters to assess the impact of plant extracts on cell function (Gray et al., 2016). Parameters such as sperm count, mobility, and sperm morphology are recognized as the fertility index in males (Woode et al., 2011; Smith et al., 1977). Thus, the extract from Alchornea cordifolia, which significantly increases the mobility of sperm, may have positive effects on male fertility. Improving the quality and quantity of spermatozoa is dependent on the quality of spermatogenesis and its transit to the caudal epididymis (Zougrou, 2017). Therefore, the increase in the sperm count in the caudal epididymis observed during this study could be explained by the ability of the extract to interfere with the spermatogenetic process in the seminiferous tubules and with the epididymal function. It may also interfere with the activity of testosterone on hypothalamic releasing factors and the anterior pituitary secretion of gonadotropins. These interferences may result in the improved spermatogenesis observed in rats treated with ETAAC. Hence, these results corroborate with those of Ajibade and Olayemi (2015). Also, some authors have reported that motility was considered to be an important factor in fertilization success and any negative impact of mobility would result in adverse effects on fertilization capacity (Dinithi et al., 2015). In this study, a significant increase in sperm mobility in the treated batches shows the effectiveness of the extract on male fertility.

The morphometric and histological study carried out on the structure of the testis of the treated subjects revealed an increase in the volume of the seminiferous tubes as well as an abundance of sperm in their lumen. These results confirm the high sperm concentration observed in the caudal epididymis of the treated rats. They may also be linked to the increased serum testosterone levels induced by the extract.

\section{Conclusion}

In conclusion, the results show that the aqueous extract of Alchornea cordifolia could be used as a remedy for male fertility problems. This is justified by the ability to develop androgen-dependent organs, stimulate the production of testosterone, and increase the quality of sperm. This study also revealed the potential of the leaf extract of Alchornea cordifolia, which acted positively on the male reproductive system. The improvement in semen quality and observed reproductive performance justify its use in traditional medicine in the treatment of male infertility. 


\section{References:}

1. Adewunmin, C.O., Agbedahunsi, J.M., Adebajo, C.A., Aladesanmi, A.J., Murphy, N. \& Wando, J. (2001). Criblage des plantes médecinales nigériennes pour les proprétés trypanocidales. $J$ Ethnopharmacol ; 77(1): 19-24.

2. Agarwal, S.S., Chauhan, S. \& Mathur, R. (1986). Antifertility effects of embelin in male rats. Andrologia; 2125-131.

3. Ajibade, T.O. \& Olayemi, F.O. (2015). Reproductive and toxic effects of methanol extract of Alchornea cordifolia leaf in male rats. Andrologia; 47(9): 1034-1040.

4. Akassa, H., Nkounkou, G.S.M., Badzi, C.N., Ossibi, A.W.E., H.H. T. \& Abena, A. (2019).- Effets de l'extrait aqueux des écorces de tronc de pausinystalia yohimbe sur la qualité de la semence et les performances de reproduction chez le rat mâle wistar Int. J. of Multidisciplinary and Current research; 7(1): 732-740.

5. Ansah, C., Duwiejua, M., Oppong, E., \& Woode, E. (2009). Toxicity study on Alchornea cordifolia leaf extract in mice. Journal of science and technology; 29(1): 8-16.

6. Ansah, C., Oppong, E., \& Woode, E. (2011).- Subacute oral toxicity assessment of Alchornea cordifolia (Schumach and thonn) mull arg (Euphorbiaceae) extract in rats. Tropical journal of pharmaceutical research; 10(5): 587-594.

7. Bélanger, B. (1992). Adrenal steroidogenesis in the guinea pig: effects of androgens. Steroids; 57(2): 76-81.

8. Clermont, Y. (1972). The cycle of the seminiferous epithelium in man. Americ. Journ. of Anat.; 11235.

9. Dinithi, L., Peiris, C., Dhanushka, M.A.T., \& Jayathilake, T.A.H.D.G. (2015). Evaluation of aqueous leaf extract of Cardiospermum halicacabum (L.) on fertility of male rats. BioMed Research International; $11-6$.

10. Edouard Akono-Nantia, Paul F. Moundipa, Nathalie Sara E. Beboy, Thomas K. Monsees, \& Carreau S. (2007). Etude de l'effet androgénique de I 'extrait au méthanol de Basella alba L. (Basellaceae) sur la fonction de reproduction du rat male. Andrologie; 17(2): 129-133.

11. Gray, S.L., Lackey, B.R., \& Boone, W.R. (2016). Effects of Panax ginseng, zearalenol, and estradiol on sperm function. Journal of Ginseng Research; 40, 251-259.

12. Lejeune, H. (1999). Panorama de I'infertilite masculine. Andro.; 9927.

13. Marzouk, K. (2017). Les kystes de la vésicule séminale. 134. 
14. Ngaha-Njila, M.I., Lembè, D.M., Koloko, B.L., Meng, G.Y., Ebrahimi, M., Awad, E.A., Baiee, F.H., Kenmogne, H., Hambe, M., \& Mandenguè, S.H. (2019). Sperm parameters quality and reproductive effects of methanolic extract of Alchornea cordifolia leaves on senescent male rats. Andrologia; 110.

15. Ngoula, F., Watcho, P., Dongmo, M.C., Kenfack, A., Kamtchouing, P., \& Chamboué, J. (2007). The Study of the Radiation Protection of Aged Garlic Extract to the Radiation Effects in Male Rat's Sperm African Health Sces; 3, 1680-1685.

16. Schlosser, J., Nakib, I., Carré-Pigeon, F., \& Staerman, F. (2007). Infertilité masculine: définition et physiopathologie. Encycl Med Chir; 186.

17. Smith, K.D., Rodriguez-Rigau, I.J., \& Steinberger, E. (1977). Relation between indices of semen analysis and pregneancy rate in infertile couples. Fertil. Steril.; 28(12): 1314-1319.

18. Stocco, D.M. (2002). Clinical disorders associated with abnormal cholesterol transport: mutations in the steroidogenic acute regulatory protein Molecular Cells Endocrinology; 19, 119-25.

19. Tamboura, H.H. (2006). Activité biologique des extraits aqueux de Holarrhena floribunda (G.Don) Durand \& Schinz (Apocynaceae) : Etude des effets de type hormone mâle chez le rat Thèse de doctorat: 186.

20. Thakur, M. \& Dixit, V.K. (2007). Aphrodisiac activity of Dactilorhiza hatagirea (D.Don) Soo in Male Albino Rats. Evid. Based complement Med.; 4(1): 29-31.

21. Weinbauer, G.F. \& Nieschlag, E. (1998.). Andrology, Male Reproductive Health and Dysfunction. Biomedicine \& Pharmacotherapy; 52(10): 11-59.

22. Woode, E., Alhassan, A., \& Abaidoo, C.S. (2011). Effect of ethanolic fruit extract of Xylopia aethiopica on reproductive function of male rats. Int. J. Pharm. Biomed. Res.; 2(3): 161-165.

23. Zougrou, N.E. (2017). Evaluation des effets toxicologiques et pharmacologiques d'un extrait aqueux de cnestis ferruginea vahl ex dc. (connaraceae) sur le systeme reproducteur des rats male et femelle. Thèse de Doctorat: 267. 